\title{
DENK. Factoren voor het succes, de kenmerken van de achterban en het bereiken van nieuwe stemmers
}

\author{
Floris Vermeulen \& Maria Kranendonk ${ }^{*}$
}

DENK heeft zich de afgelopen jaren stormachtig ontwikkeld. De eerste multiculturele partij in West-Europa met vertegenwoordigers in het nationale parlement en in verschillende gemeenteraden. Dit electorale succes is vooral te danken aan een uitzonderlijk hoge steun onder stemmers met een Turkse of Marokkaanse achtergrond. Zo haalde DENK bij de afgelopen parlementsverkiezingen meer dan 50 procent van de stemmen onder Turkse Nederlanders en kreeg het bij de laatste gemeenteraadsverkiezingen in Amsterdam bijna driekwart van alle Turkse stemmen (Vermeulene.a., 2018; Kranendonk e.a., 2018). Men kan deze ontwikkeling voor een belangrijk deel zien als het politieke emancipatieproces van Nederlandse moslims. DENK komt specifiek op voor de belangen van deze groep en de partij krijgt met name steun van stemmers met een islamitische achtergrond (Otjes \& Krouwel, 2018; Vermeulen e.a., 2018; Santing \& Vermeulen 2018).

In deze bijdrage gaan we kort in op de belangrijkste factoren die het succes van DENK verklaren en op de kenmerken en achtergronden van de DENK-stemmers en richten ons vervolgens op de belangrijkste vraag voor dit artikel: in hoeverre is DENK erin geslaagd een groep nieuwe stemmers naar de stembus te trekken die in het verleden door het ontbreken van een dergelijke multicultureel politiek alternatief niet participeerden?

\section{Succes}

Het succes van DENK is in belangrijke mate te verklaren door de groeiende invloed van het anti-islam- en anti-immigratiediscours van Wilders van de afgelopen jaren. Het succes van Wilders heeft er onder andere voor gezorgd dat alle partijen in het parlement, inclusief progressieve partijen zoals GroenLinks en de PvdA, inzake diversiteit en integratie naar rechts zijn opgeschoven (Van Heerden e.a., 2014). Dat zijn partijen die in het verleden, en dan met name de PvdA, grote steun genoten onder Turks- en Marokkaans-Nederlandse stemmers (Vermeulen, Michon \& Tillie, 2014). Daarnaast heeft een deel van deze gemeenschappen, deels door het in hun ogen vijandige klimaat in Nederland ten aanzien van moslims, zich teruggetrokken in de eigen groep. Zo liet het Sociaal en Cultureel Planbureau (SCP) zien dat een groot deel van de Turks- en Marokkaans-Nederlandse jongeren (rond de 25 procent) zich niet of nauwelijks verbonden voelde met de Neder-

* Dr. Floris Vermeulen is werkzaam op de afdeling Politicologie van de Universiteit van Amsterdam. Drs. Maria Kranendonk, MSc is werkzaam op de afdeling Politicologie van de Universiteit van Amsterdam. 
landse samenleving (Huijnk e.a., 2015). De frustratie over de traditionele politieke partijen binnen deze gemeenschappen is de afgelopen jaren sterk gegroeid. Een belangrijk kantelpunt in dit proces waren de discussies rond het verbod op ritueel slachten (2015). Progressieve seculiere partijen, die Turks- en Marokkaans-Nederlandse stemmers in grote mate hadden gesteund, leken hier zonder veel discussie met de achterban een tegengestelde positie in te nemen (Vermeulen, 2018).

DENK kan in vergelijking met de progressieve partijen veel directer en zichtbaarder opkomen voor de specifieke belangen van deze groepen. De partij hoeft geen rekening te houden met de belangen en/of standpunten van andere groepen kiezers. Daarnaast is DENK in staat gebleken gebruik te maken van het goed georganiseerde en meer conservatieve religieuze deel van de Turks-Nederlandse gemeenschap. Een dicht en uitgebreid netwerk van organisaties, zoals moskeeën en sociaal-culturele verenigingen, hebben de partijleiders, die al jaren actief zijn binnen deze netwerken, direct toegang gegeven tot grote groepen potentiële kiezers (Vermeulen e.a., 2018; Santing \& Vermeulen, 2018).

\section{Achterban}

Hoe ziet die achterban van DENK eruit? Zoals gezegd geniet DENK grote populariteit onder stemmers die zichzelf als moslim identificeren en dan met name stemmers die een Turkse en in iets mindere mate een Marokkaanse achtergrond hebben. DENK is populair onder jonge kiezers; hierbij speelt het sterke optreden van de partij en haar leiders op sociale media een belangrijke rol, maar ook dat deze groep kiezers minder loyaal is aan de PvdA dan hun ouders (Otjes \& Krouwel, 2018; Santing \& Vermeulen, 2018), en DENK is met name populair onder laagopgeleide kiezers in deze groep. De steun voor DENK onder stemmers zonder een migratieachtergrond is klein (bij de Amsterdamse gemeenteraadsverkiezingen rond de 2 procent) (Kranendonk e.a., 2018; Vermeulen e.a., 2018).

DENK-stemmers nemen ten aanzien van morele vraagstukken als euthanasie of de emancipatie van homoseksuelen over het algemeen conservatieve posities in, waarbij men dichter bij stemmers van de ChristenUnie en SGP staat dan bij de PvdA. Ten aanzien van vraagstukken als immigratie, integratie, discriminatie en islam nemen DENK-stemmers juist standpunten in die politicologen over het algemeen identificeren al progressief. Ten aanzien van sociaaleconomische onderwerpen zoals bijvoorbeeld inkomensverdeling blijken DENK-stemmers geen uitgesproken links profiel te hebben, ondanks het feit dat een relatief groot deel van hen in het verleden wel op de PvdA heeft gestemd (Otjes \& Krouwel, 2018; Vermeulen e.a., 2018).

Een belangrijke vraag in de context van het politieke emancipatieproces is de vraag in hoeverre DENK in staat is gebleken mensen naar de stembus te trekken die dat voorheen niet deden omdat er geen aansprekende multiculturele partij beschikbaar was. We richten ons hier op Amsterdam omdat we daar de meest geschikte data voor handen hebben (Kranendonk e.a., 2018). 
Voor bepaalde groepen lijkt DENK zeker weer leven in het politieke bewustzijn geblazen te hebben. Als we bijvoorbeeld kijken naar de opkomstpercentages van de parlementsverkiezingen van 2017 zien we dat in Nieuw-West, het stadsdeel met de grootste concentratie stemmers met een Turkse of Marokkaanse achtergrond (samen 33 procent van de bevolking in dit stadsdeel), bijna 72 procent naar de stembus ging, 12 procent hoger dan de verkiezing van 2012 en een van de grootste stijgingen in Amsterdam. DENK haalde in dit stadsdeel 19,4 procent van de stemmen, met uitschieters in bepaalde wijken van bijna 30 procent. In het stadsdeel waren er voor de verkiezingen verschillende bijeenkomsten waarbij jongeren met politici in gesprek gingen, en op de sociale media waren DENK en de verkiezingen trending topics, zaken die in het verleden niet of nauwelijks aan de orde waren (Santing \& Vermeulen, 2018).

\section{Opkomst}

Voor de hele stad zien we bij de gemeenteraadsverkiezingen van 2018 een beduidende hogere opkomst onder stemmers met een Turkse achtergrond in vergelijking tot 2014. Zoals we al eerder aangaven, is DENK met name onder deze groep stemmers populair. We zien ook een sterk positief verband tussen buurten waar veel mensen van Turkse afkomst wonen en het aantal stemmen dat de partij daar weet te bemachtigen (Vermeulen e.a, 2018). Onder andere groepen, ook onder stemmers met een Marokkaanse afkomst, is die aantrekkingskracht minder groot. Het opkomstpercentage onder Surinaamse of Marokkaanse Amsterdammers is gelijk gebleven en blijft structureel laag (Kranendonk e.a., 2018). Figuur 1 laat de opkomstpercentages van de grootste groepen met een migratieachtergrond zien. Het is DENK met een Amsterdamse lijsttrekker van Marokkaanse afkomst niet gelukt om meer Marokkaanse Amsterdammers naar de stembus te trekken. Meer dan drie kwart van deze groep heeft niet de moeite genomen om zijn of haar stem uit te brengen. Hetzelfde kan overigens gesteld worden voor BIJ1, die weliswaar de grootste steun heeft onder Surinaamse Amsterdammers, maar die er ook niet voor gezorgd heeft dat het structurele lage opkomstpercentage onder deze groep is gestegen.

We hebben vervolgens de DENK-stemmers uitgesplitst naar of zij (1) bij de gemeenteraadsverkiezingen van 2014 mochten stemmen, (2) of zij ervoor kozen niet te stemmen terwijl ze dat wel mochten, of (3) dat ze wel hebben gestemd. Daarbij hebben we rekening gehouden met leeftijd, geslacht, generatie en opleidingsniveau. Dit geeft verder inzicht in welke groepen inactieven DENK heeft kunnen aantrekken in de gemeenteraadsverkiezingen van 2018.

\section{Politiek emanciperend}

Onder de voormalig inactieve DENK-stemmers bevinden zich meer jongeren met een leeftijd tot 29 jaar (39 procent) in vergelijking tot de voormalig actieve 


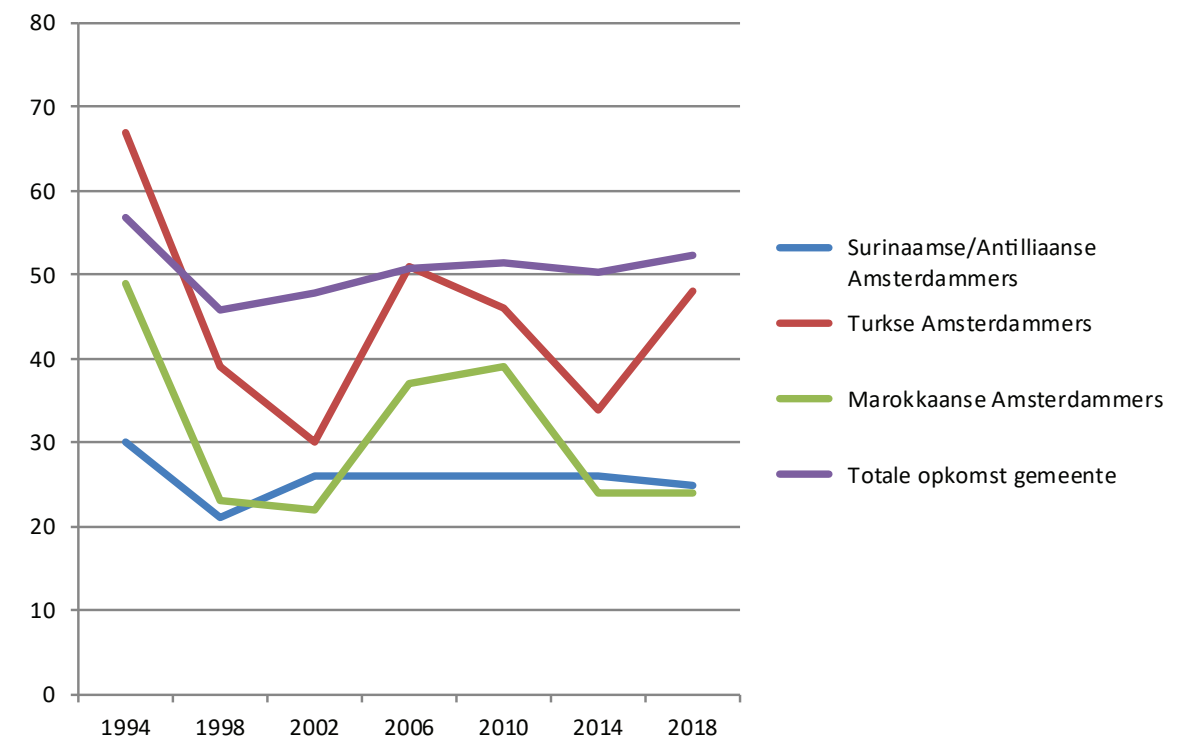

Figuur 1 Opkomstpercentages van vier herkomstgroepen bij de Amsterdamse gemeenteraadsverkiezingen voor de periode 1994-2018 (Kranendonk e.a., 2018)

DENK-stemmers (21 procent); de kiezers die in 2014 niet mochten stemmen laten we hier verder buiten beschouwing. Dit beeld wordt versterkt als we de resultaten uitsplitsen naar generaties. Onder de voormalig inactieve DENK-stemmers waren meer tweedegeneratiemigranten (45 procent) in vergelijking tot de voormalig politiek actieve DENK-stemmers (30 procent). Dit wijst erop dat DENK, zoals eerder ook gesteld, met name in staat is gebleken om een relatief jong electoraat aan te trekken dat voorheen politiek inactief was. Er lijken ook meer vrouwen te zitten tussen de voormalig inactieve DENK-stemmers (60 procent) in vergelijking tot de voormalig actieve DENK-stemmers (50 procent). We zien geen verband tussen het opleidingsniveau en de voormalig actieve en inactieve DENK-stemmers. Ten slotte zien we onder stemmers met een Marokkaanse achtergrond dat DENK populairder is onder de voorheen inactieve stemmers (66 procent) dan onder de voorheen actieve stemmers (48 procent). Blijkbaar heeft de partij onder deze groep toch ook een nieuwe groep kiezers aangeboord; dat heeft echter niet geleid tot een hoger opkomstpercentage onder deze groep in zijn geheel.

Concluderend kunnen we stellen dat er verschillende signalen zijn die erop wijzen dat DENK een politiek emanciperend effect heeft op haar achterban. Het geeft moslims van met name Turkse en iets mindere mate Marokkaanse afkomst een stem in het parlement en in de gemeenteraden van grote steden. Iets wat in het verleden door progressieve seculiere partijen gedaan werd. Daarnaast heeft DENK een relatief grote aantrekkingskracht op laagopgeleiden, jongeren en vrouwelijke 
stemmers. Dat zijn sociaaleconomisch gezien de meest kwetsbare en politiek gezien de meest inactieve groepen binnen deze gemeenschappen.

\section{Literatuur:}

Heerden, S. van, Lange, S.L. de, Brug, W. van der, \& Fennema, M. (2014). The immigration and integration debate in the Netherlands: Discursive and programmatic reactions to the rise of anti-immigration parties. Journal of Ethnic and Migration Studies, 40 (1): 119-136.

Huijnk, W., Dagevos, J., Gijsberts, M., \& Andriessen, I. (2015). Werelden van verschil. Over de sociaal-culturele afstand en positie van migrantengroepen in Nederland. Den Haag: SCP.

Kranendonk, M., Lekkerkerker, E., Michon, L., \& Vermeulen, F. (2018). Opkomst en stemgedrag van Amsterdammers met een migratie-achtergrond tijdens de gemeenteraadsverkiezingen van 21 maart 2018. Amsterdam: OIS.

Otjes, S., \& Krouwel, A. (2018). Why do newcomers vote for a newcomer? Support for an immigrant party. Journal of Ethnic and Migration Studies. http://doi.org/10.1080/ 1369183X.2018.1427053.

Santing, F., \& Vermeulen, F. (2018, 21 februari). Diversiteit is een kracht. Hoe DENK Amsterdam Nieuw-West verovert. De Groene Amsterdammer.

Vermeulen, F. (2018). The Paradox of Immigrant Political Participation in Europe amidst Crises of Multiculturalism. In: C. Menjivar, M. Ruiz \& I. Ness (red.). The Oxford Handbook of Migration Crises. Oxford: Oxford University Press. DOI: 10.1093/oxfordhb/ 9780190856908.013.26.

Vermeulen, F., Harteveld, E., Heelsum, A. van, \& Veen, A. van der (2018). The potential of immigrant parties: insights from the Dutch case. Acta Politica, 1-22. DOI: 10.1057/ s41269-018-0123-z).

Vermeulen, F., Michon, L., \& Tillie, J. (2014). Immigrant political engagement and incorporation in Amsterdam. In: N. Foner, J. Rath, J.W. Duyvendak \& R. van Reekum (red.). Immigration and the New Urban Landscape: New York and Amsterdam. New York: New York University Press, 230-256. 